\title{
50Hz Extremely Low Frequency Electromagnetic Fields Enhance Protein Carbonyl Groups Content in Cancer Cells: Effects on Proteasomal Systems
}

\author{
A. M. Eleuteri, ${ }^{1}$ M. Amici, ${ }^{1}$ L. Bonfili, ${ }^{1}$ V. Cecarini, ${ }^{1}$ M. Cuccioloni, ${ }^{1}$ S. Grimaldi, ${ }^{2}$ \\ L. Giuliani, ${ }^{3}$ M. Angeletti, ${ }^{1}$ and E. Fioretti ${ }^{1}$ \\ ${ }^{1}$ Department of Biology M.C.A., University of Camerino, 62032 Camerino (MC), Italy \\ ${ }^{2}$ Institute of Neurobiology and Molecular Medicine, Division of Medicine, CNR, 00143 Rome, Italy \\ ${ }^{3}$ Istituto Superiore Prevenzione e Sicurezza Lavoro (ISPESL), Division of Venice, 30172 Venezia, Italy
}

Correspondence should be addressed to A. M. Eleuteri, annamaria.eleuteri@unicam.it

Received 26 February 2009; Revised 14 May 2009; Accepted 5 June 2009

Recommended by Francesca Cutruzzolà

\begin{abstract}
Electromagnetic fields are an assessed cause of prolonging free radicals lifespan. This study was carried out to investigate the influence of extremely low frequency electromagnetic fields on protein oxidation and on the $20 \mathrm{~S}$ proteasome functionality, the complex responsible for the degradation of oxidized proteins. Caco 2 cells were exposed, for $24-72$ hours, to $1 \mathrm{mT}, 50 \mathrm{~Hz}$ electromagnetic fields. The treatment induced a time-dependent increase both in cell growth and in protein oxidation, more evident in the presence of TPA, while no changes in cell viability were detected. Exposing the cells to $50 \mathrm{~Hz}$ electromagnetic fields caused a global activation of the $20 \mathrm{~S}$ proteasome catalytic components, particularly evident at 72 hours exposure and in the presence of TPA. The finding that EGCG, a natural antioxidant compound, counteracted the field-related pro-oxidant effects demonstrates that the increased proteasome activity was due to an enhancement in intracellular free radicals.
\end{abstract}

Copyright (C) 2009 A. M. Eleuteri et al. This is an open access article distributed under the Creative Commons Attribution License, which permits unrestricted use, distribution, and reproduction in any medium, provided the original work is properly cited.

\section{Introduction}

The effects of the exposure to extremely low frequency electromagnetic fields (ELF-EMFs), generated by power lines and household electric appliances, have been receiving increasing interest for the feasible harmful effects on human health. The abovementioned human-made fields have a different wave form, coherence, and frequency with respect to natural EMFs, and their effects on living biological systems are far from being completely understood. Substantially, human-made EMFs are above the naturally occurring electric and magnetic fields. The average $B$ value of the static geomagnetic field is $40 \times 10^{-6}$ T approximately $[1,2]$.

A variety of biological hazards, partly attributable to an increased level of free radicals, were associated with the exposure to ELF-EMFs [3-5]. In cellular models, a significant postexposure increase in reactive oxygen species (ROS) has been reported, suggesting that ELF-EMFs are able to induce the activation of cellular processes in the investigated models $[4,5]$. Additionally, ELF-EMFs were likely to cause an increase in free radicals lifetime in cells $[6,7]$. Besides that, ELF-EMFs have been shown to alter second messenger pathways such as calcium signalling $[1,8]$, thus leading to downstream physiological effects. In fact, $50 \mathrm{~Hz}$ EMFs have been reported to produce an increase in the intracellular calcium level in the pituitary corticotropederived AtT20 D16 V cells, and a consequent rearrangement of the cytoskeletal network [9].

Several epidemiological studies reported evidences suggesting a link between ELF-EMFs exposure and cancer risk $[1,10,11]$. These observations were supported by cellular studies reporting the electromagnetic field-induced effects on biological systems, most notably on the activity of components implicated in the regulation of cell proliferation $[1,12,13]$.

Nevertheless, it is still unclear whether and how the exposure to ELF-EMFs promotes carcinogenesis. Mutagenic effects have been extensively described, such as a global 
increase in the frequency of chromosomal aberrations [14], in micronuclei formation [15], or in DNA strand breaks [16].

Only limited data are currently available on the specific effects of ELF-EMFs on enzyme functionality, although it is believed that they can affect enzyme activity $[1,7,13,17-$ 20]. In this perspective, our attention has been focused on the effects of ELF-EMFs exposure on enzymes that regulate cellular homeostasis, the proteasome in particular. Tumor suppressors, cell-cycle regulators, transcription factors, and antiapoptotic proteins are examples of proteasome substrates [21-23]. The cyclin dependent kinase p27, known as a proapoptotic protein, is an important regulator of the cell cycle progression, controlling the $G_{1} / S$ transition, where it reaches the highest concentration. Its cellular levels are modulated by the proteasome-dependent degradation, and its decrease has been related to an activation of the proteasome functionality, preventing the cell from undergoing apoptosis [24].

The $20 \mathrm{~S}$ proteasome plays a central role in the cellular antioxidant defence, since partially folded, unfolded, and oxidized proteins [25-28], as well as proteins with the reduction of disulfide bonds, are susceptible to proteasomal degradation. The $20 \mathrm{~S}$ proteasome is a member of the $\mathrm{N}$ terminal nucleophile hydrolases family (Ntn-hydrolases), a class of enzymes that catalytically use an N-terminal residue as both a polarizing base and a nucleophile [29]. In eukaryotic proteasomes only three $\beta$ subunits $(\beta 1, \beta 2$, and $\beta 5$ ) are catalytically active, each linked to a specific catalytic component: the "peptidylglutamyl-peptide hydrolizing" (PGPH, cleaving after acidic residues), the "trypsin-like" (T-L, cleaving after basic residues), and the "chymotrypsin-like" (ChT-L, cleaving after hydrophobic residues) activities, respectively [30-32]. In addition, two more catalytic activities, namely, the BrAAP (cleaving bonds after branched chain and aromatic amino acids) and the SNAAP (cleaving after small neutral amino acids), were reported [33].

Among the modulators of the $20 \mathrm{~S}$ proteasome activity, the polyphenolic compound epigallocatechin-3-gallate (EGCG), the major component of green tea, has been demonstrated to possess a strong free radical scavenging effect in several cell lines [34-39].

Considering the key role of the proteasome in the removal of oxidized proteins and in the regulation of the cell cycle progression, in the present paper we have investigated the effect of ELF-EMFs on the 20 S proteasome functionality. Furthermore, EGCG protective action towards ELF-EMFs mediated oxidative damage has been also evaluated.

\section{Materials and Methods}

2.1. Materials. The Oxidized Protein Detection Kit was purchased from Appligene-Oncor (Strasbourg, France). Substrates for assaying the ChT-L, T-L and PGPH activities (Suc-Leu-Leu-Val-Tyr-AMC, Z-Leu-Ser-Thr-Arg-AMC, and Z-Leu-Leu-Glu-AMC) were purchased from SigmaAldrich S.r.l. (Milano, Italy). The Z-Gly-Pro-Ala-Leu-AlapAB substrate was the kind gift of Professor M. Orlowski (Department of Pharmacology, Mount Sinai School of
Medicine, New York, USA). 12-O-tetradecanoylphorbol13-acetate (TPA) and (-)epigallocatechin-3-gallate (EGCG) were purchased from Sigma-Aldrich S.r.l. EGCG was used directly without further purification and was dissolved in assay buffer (Tris- $\mathrm{HCl} 50 \mathrm{mM}, \mathrm{pH} 8.0$ ).

The mouse antihuman p2 $7^{\mathrm{kip}-1}$ polyclonal antibody was obtained by Inalco S.p.A. (Milano, Italy). The rabbit antiGAPDH (FL-335) polyclonal antibody was purchased from Santa Cruz Biotechnology Inc. Rabbit polyclonal antibodies to "core" subunits of the human 20S proteasome were purchased from Biomol International LP, UK. SigmaMarker, Wide Molecular Weight Range protein standards for SDSPAGE were obtained from Sigma-Aldrich S.r.l. All chemicals and reagents were of the highest grade available.

2.2. Cell Culture. The human colon adenocarcinoma cell line Caco 2 (Istituto Zooprofilattico Sperimentale Lombardia ed Emilia Romagna, Italy) was cultured in D-MEM medium (Gibco Invitrogen Cell Culture, Milano, Italy) supplemented with $15 \%$ fetal calf serum, $0.4 \%$ L-glutamine, $1 \%$ non essential amino acids, penicillin, and streptomycin. Cells were maintained in a $5 \% \mathrm{CO}_{2}$ atmosphere at $37^{\circ} \mathrm{C}$.

Cells were grown in $100 \mathrm{~mm}$ tissue culture dishes at an initial concentration of $4 \times 10^{5}$ cells $/ \mathrm{mL}$ in a total volume of $15 \mathrm{~mL}$. After a 24-hour starvation without serum, cells were continuously exposed to a sinusoidal $50 \mathrm{~Hz}$ magnetic field at a flux density of $1 \mathrm{mT}$ (rms) in a solenoid for 24, 48, and 72 hours. Control samples were placed under the same conditions in a solenoid with no EM field applied. The stray field inside the nonpowered solenoid was $<0.5 \mu \mathrm{T}$. Both samples were placed into a water-jacketed, thermo-regulated and atmosphere-controlled incubator $\left(37.0 \pm 0.5^{\circ} \mathrm{C}\right.$ and $\left.5 \% \mathrm{CO}_{2}\right)$. All experiments were performed under blind conditions. Caco cells were cultured in the presence and absence of $150 \mu \mathrm{M}$ EGCG and in the presence and absence of $0.1 \mu \mathrm{M}$ TPA [34].

After removing the medium and washing with cold PBS, cells were harvested in $3 \mathrm{ml}$ PBS. An aliquot was withdrawn for counting. After centrifuging at $1600 \mathrm{rpm}$ for 5 minutes, the pellet was homogenized in a lysis buffer $(20 \mathrm{mM}$ Tris, $\mathrm{pH} 7.4,250 \mathrm{mM}$ sucrose, $1 \mathrm{mM}$ EDTA, and $5 \mathrm{mM} \beta$ mercaptoethanol) and passed through a 25-gauge needle for at least ten times. Lysates were centrifuged at $12000 \times$ $\mathrm{g}$ for 15 minutes, and the supernatants were stocked at $-80^{\circ} \mathrm{C}$. Protein concentration in cell lysates was determined by Bradford method [40] using bovine serum albumine as a standard.

2.3. Electromagnetic Field Exposure. ELF-EMFs were generated by a $20 \mathrm{~cm}$ diameter $\times 40 \mathrm{~cm}$ length solenoid. The solenoid was wound in three forward-backward-forward continuous layers with 600 turns of $2 \mathrm{~mm}$ diameter copper wire.

It was driven by the $50 \mathrm{~Hz}$ power line through with a variable autotransformer and generated a magnetic flux density of $1 \mathrm{mT}$ (rms) for an applied voltage of $6 \mathrm{~V}$ (rms) $[9,41]$. The solenoid was positioned into a waterjacketed temperature and atmosphere regulated incubator 


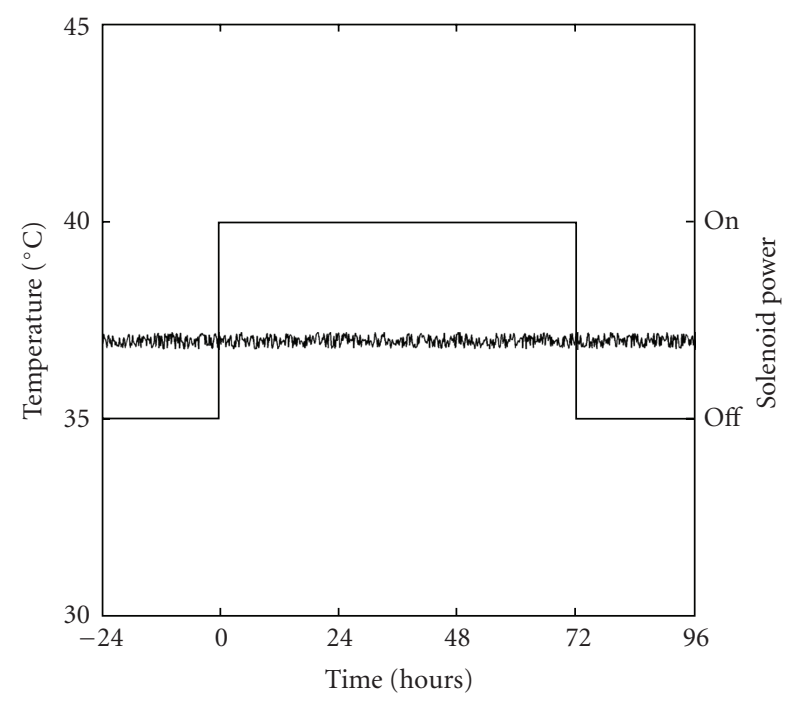

Figure 1: Temperature monitoring of exposed samples over time. Direct monitoring of treated sample temperatures before, during and after exposure was performed using a digital multimeter (METEX Mod. M-3630D) equipped with ScopeView software (vers. 1.06) for data logging (the acquisition was carried out at $0.0028 \mathrm{~Hz}$ ). The temperature probe was placed within the center of the solenoid in a culture dish containing medium with no cells.

$\left(37.0 \pm 0.5^{\circ} \mathrm{C}\right.$ and $\left.5 \% \quad \mathrm{CO}_{2}\right)$. The dishes were placed horizontally into the solenoid, so that the magnetic flux was parallel to the bottom. Moreover, dishes were placed in a volume determined by measurements of field variations inside the solenoid. In fact, field intensity, measured with a calibrated Chauvin Arnoux gaussmeter, was within - 5\% of centre value inside the cylindrical exposure volume of $11 \mathrm{~cm}$ by $17 \mathrm{~cm}$ along the solenoid axis. Cells were exposed in continuous to a $50 \mathrm{~Hz}$ magnetic field at a flux density of $1 \mathrm{mT}$ (rms) for 24, 48 and 72 hours. Control samples were placed in a solenoid with no field applied positioned into a second identical water-jacketed temperature and atmosphere regulated incubator. The stray field inside the nonpowered solenoid was $<0.5 \mu \mathrm{T}$.

Direct monitoring of sample temperatures before, during, and after exposure for both the control and exposed conditions was performed in continuous using a digital multimeter (METEX Mod. M-3630D) controlled by ScopeView software (vers. 1.06) for data logging (the acquisition was carried out at $0.0028 \mathrm{~Hz}$ ). The temperature probe was placed within the centre of the solenoid (either energized or not) in a culture dish containing medium with no cells: no significant temperature difference between culture media of exposed or unexposed dishes was revealed. Samples temperature was $37.0 \pm 0.3^{\circ} \mathrm{C}$; see Figure 1 .

2.4. Cell Viability. Cell viability was determined by 3-(4,5dimethylthiazol-2-yl)-2,5-diphenyltetrazolium bromide (MTT) conversion as previously described [42, 43]. Briefly, following experimental treatment, cells were washed in phosphate-buffered saline solution (PBS, $\mathrm{pH} 7.5$ ), and then

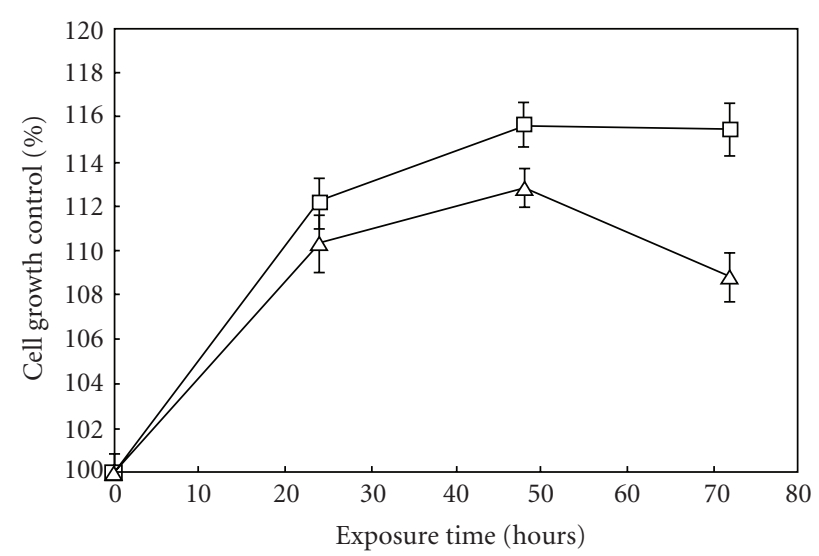

Figure 2: Effect of ELF-EMFs exposure on Caco cells proliferation rate. Cells were continuously exposed to $1.0 \mathrm{mT}, 50 \mathrm{~Hz}$ ELF-EMF; control cells were grown under the same conditions in a not energized solenoid. After 24, 48, and 72 hours cells were harvested and counted: the proliferation rate of treated cells was reported as percent of control unexposed cells. Data are mean $\pm \mathrm{SE}$ of six separate experiments: $(\square) 0 \mu \mathrm{M} \mathrm{TPA} ;(\Delta) 0.1 \mu \mathrm{M}$ TPA.

MTT (final concentration $0.5 \mathrm{mg} / \mathrm{ml}$ ) was added to culture medium without fetal calf serum and incubated for 2 hours at $37^{\circ} \mathrm{C}$. The medium was then removed and replaced with $100 \mu \mathrm{L}$ of DMSO. The optical density was measured at $550 \mathrm{~nm}$ with a microtiter plate reader. At least six cultures were utilized for each time point.

2.5. Measurements of $20 \mathrm{~S}$ Proteasome Activities. The ChTL, T-L, PGPH, and BrAAP activities in cell lysates were determined with a Shimadzu RF5300 spectrofluorometer as previously reported $[33,44,45]$, using $5 \mu \mathrm{M}$ Suc-Leu-LeuVal-Tyr-AMC, $5 \mu \mathrm{M}$ Z-Leu-Ser-Thr-Arg-AMC, $5 \mu \mathrm{M}$ Z-LeuLeu-Glu-AMC, and $0.5 \mathrm{mM}$ Z-Gly-Pro-Ala-Leu-Ala-pAB, respectively, as substrates. Cell lysates ( $5 \mu \mathrm{g}$ total proteins) were incubated with the synthetic substrates in the assay buffer ( $50 \mathrm{mM}$ Tris- $\mathrm{HCl}, \mathrm{pH} 8.0$ ) up to a final volume of $500 \mu \mathrm{l}$. After 1 hour of incubation at $37^{\circ} \mathrm{C}$, the measurement of the hydrolyzed 7-amino-4-methyl-coumarin (AMC) or 4-aminobenzoic acid (PABA) was detected (AMC: $\lambda_{\mathrm{exc}}=$ $365 \mathrm{~nm}, \lambda_{\mathrm{em}}=449 \mathrm{~nm}$; PABA: $\left.\lambda_{\mathrm{exc}}=304 \mathrm{~nm}, \lambda_{\mathrm{em}}=664 \mathrm{~nm}\right)$.

Since the BrAAP component cleaves exclusively the LeuAla bond in Z-Gly-Pro-Ala-Leu-Ala-pAB, a coupled twostep reaction in the presence of excess aminopeptidase $\mathrm{N}$ (APN), $20 \mu \mathrm{g}$ of protein, (EC 3.4.11.2), [33], was used for the determination of the activity. Aminopeptidase $\mathrm{N}$ was purified from pig kidney, as reported elsewhere [46, 47].

With the aim of evaluating the $20 \mathrm{~S}$ proteasome contribution to the short peptide cleavage, control experiments were performed in the presence of specific inhibitors: Z-Gly-ProPhe-Leu-CHO $(5 \mu \mathrm{M})$ for the BrAAP activity and lactacystin $(5 \mu \mathrm{M})$ for the ChT-L component $[48,49]$.

2.6. Western Blotting. Immunoblot detection of carbonyl groups was performed with the OxyBlot oxidized protein detection kit (Appligene-Oncor, Strasbourg, France), 
according to the manufacturer. Briefly, $15 \mu \mathrm{g}$ of cell lysates were incubated for 15 minutes at room temperature with 2,4dinitrophenylhydrazine to form the dinitrophenylhydrazone carbonyl derivate and separated on a $12 \%$ SDS/PAGE. The modified proteins were then transferred to a polyvinylidene fluoride membrane (Millipore Corporation, Bedford, MA, USA) and revealed by antidinitrophenylhydrazone antibodies as specified in the OxyBlot data sheet.

Western blotting analyses using antibodies to "core" subunits of the human $20 \mathrm{~S}$ proteasome $(1: 1000)$ were carried out in order to reveal differences in the expression levels of the complex in cell lysates.

Immunoblot experiments using anti-p2 $7^{\text {kip-1 }}$ human and mouse (Mouse) monoclonal antibody $(1: 100)$ were performed by electroblotting $30 \mu \mathrm{g}$ lysates samples per lane. Each gel was loaded with molecular weight markers including proteins with MW from 6.5 to $205 \mathrm{kDa}$ (SigmaMarker Wide Molecular Weight Range, Sigma-Aldrich S.r.l.). After immunostaining, the two protein bands $(\sim 50$ and $70 \mathrm{kDa})$ were identified overlapping the film with the ComassieBrilliant Blue-stained membrane. As a control for equal protein loading glyceraldehyde-3-phosphate dehydrogenase (GAPDH) was utilized: membranes were stripped and reprobed for GAPDH using a polyclonal antibody diluted $1: 500$ (Anti-GAPDH (FL-335) rabbit polyclonal antibody from Santa Cruz Biotechnology Inc.). The immunoblot detections were carried out with Enhanced ChemiLuminescence western blotting analysis system (GE-Healthcare, Milano, Italy) using peroxidase conjugated antimouse and antirabbit secondary antibodies. A densitometric algorithm was developed to quantitate the Western Blot results. Each Western Blot film was scanned (16 bits greyscale), and the obtained digital data were processed to calculate the background mean value and its standard deviation. The background-free image was then obtained subtracting the background intensity mean value from the original digital data. The integrated densitometric value associated to each band was then calculated as the sum of the density values over all the pixels belonging to the considered band having a density value higher than the background standard deviation. The band densitometric value was then normalized to the relative GAPDH signal intensity. The ratios of band intensities were calculated within the same Western Blot. All the calculations were carried out using the Matlab environment (The MathWorks Inc., MA, USA) $[50]$.

2.7. Statistical Analysis. All data are expressed as mean values \pm SE of results obtained from six independent experiments, in which all the activities measurements were carried out in triplicate, whereas for densitometric analysis six blots were considered. Analysis of variance (ANOVA) was used to assess differences among multiple sets of data obtained with untreated and treated cells at different times of exposure. When significant values were found $(P<.05)$, post hoc comparisons of means were made using the BonferroniDunn test [51].

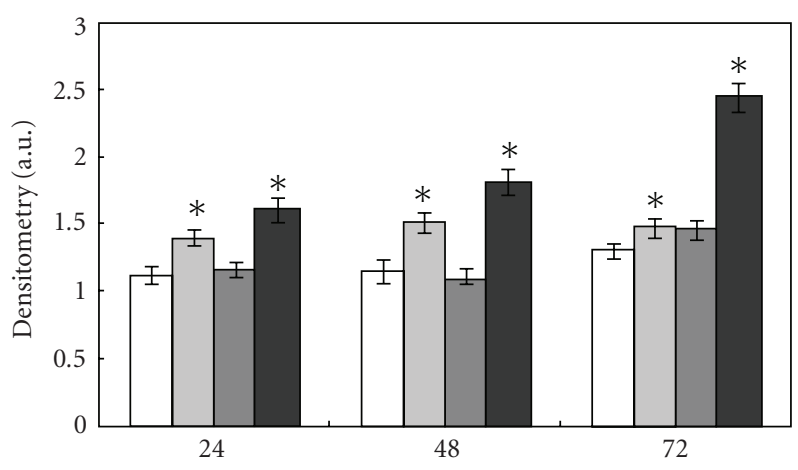

Exposure time (hours)

(a)

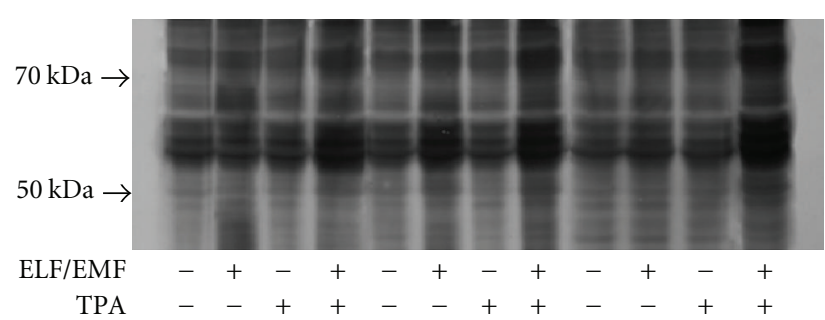

(b)

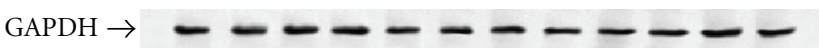

(c)

Figure 3: Effect of ELF-EMFs exposure and TPA treatment on protein oxidation. Protein oxidation was analysed and quantified by measuring the amount of protein carbonyl groups. The densitometric analysis from six separate blots provided for quantitative analysis of the amount of protein carbonyls is present (a) and a representative Western blot of protein carbonyls is shown (b). Equal protein loading was verified by using an antibody directed against GAPDH (c). Caco cells were cultured with and without $0.1 \mu \mathrm{M}$ TPA and exposed to ELM-EMFs for 24, 48, and 72 hours. After harvesting and lysing the cells, samples were treated according to the OxyBlot procedure (Oxidized Protein Detection Kit, Oncor). Carbonyl groups were revealed by appropriate antibodies using an Enhanced Chemiluminescence Western blotting analysis system. Data points marked with an asterisk are statistically significant compared to their respective not exposed control cells $(P<.05)$.

\section{Results and Discussion}

It is widely accepted that ELF-EMFs can influence several biological functions of cells and tissues, modulating intracellular ROS levels and the cell cycle progression [1, 3$5,12,13]$. The aim of this study was to investigate the effect of ELF-EMFs on cultured cells focalizing the attention on the $20 \mathrm{~S}$ proteasome functionality, the main responsible for the degradation of oxidized proteins.

Exposing Caco cells to $1 \mathrm{mT}, 50 \mathrm{~Hz}$ ELF-EMFs, resulted in a time-dependent increase in cell proliferation rate compared to unexposed control cells. In detail, at 24 hours a $10-12 \%$ increase in cell proliferation rate upon ELFEMFs exposure was evident and after 48 hours there was an increase from 12 to $16 \%$. Cell viability was essentially not affected by ELF-EMFs exposure, however several changes in 

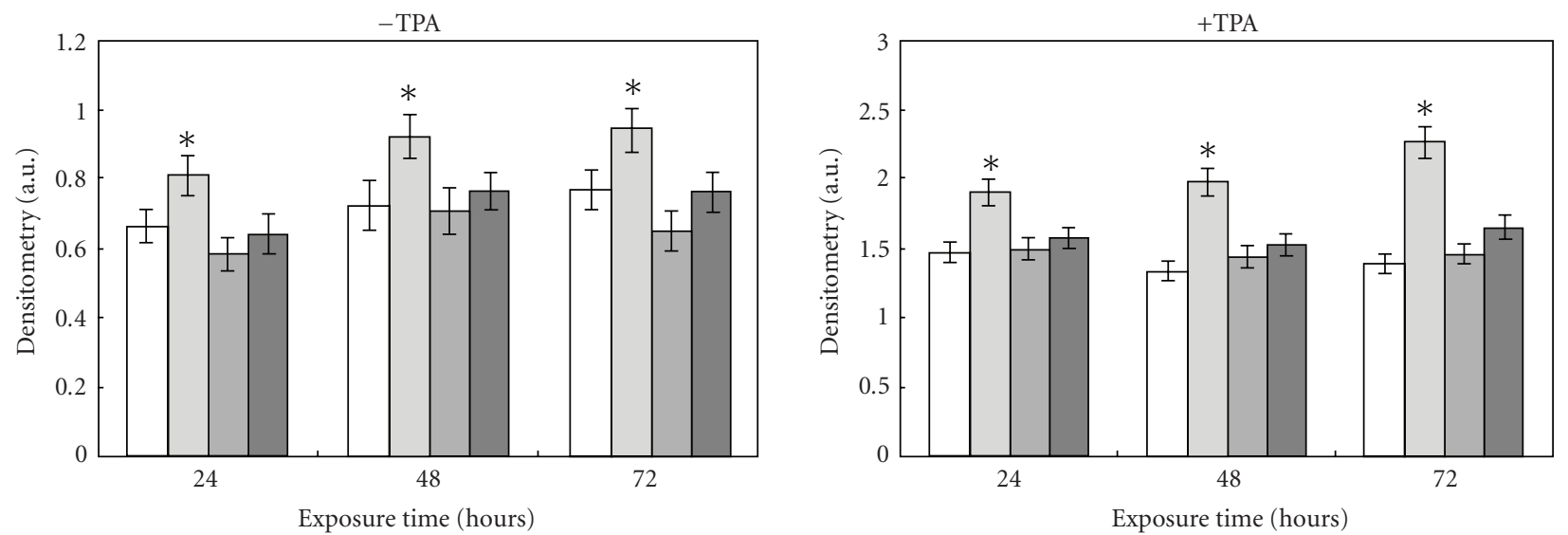

(a)
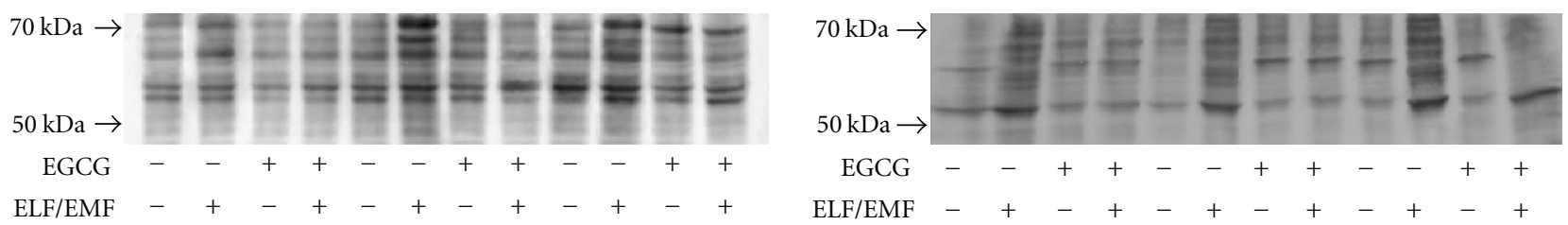

(b)

FIgURE 4: Effect of ELF-EMFs exposure and EGCG treatment on protein oxidation. Protein oxidation was analysed and quantified by measuring the amount of protein carbonyl groups. The densitometric analysis from six separate blots provided for quantitative analysis of the amount of protein carbonyls is present (panel A) and a representative Western blot of protein carbonyls is shown (panel B). Equal protein loading was verified by using an antibody directed against GAPDH (panel C). Caco cells were cultured with and without $150 \mu \mathrm{M}$ EGCG, with and without TPA and exposed to ELM-EMFs for 24, 48 and 72 hours. After harvesting and lysing the cells, samples were treated according to the OxyBlot procedure (Oxidized Protein Detection Kit, Oncor). Carbonyl groups were revealed by appropriate antibodies using an Enhanced ChemiLuminescence Western blotting analysis system. Data points marked with an asterisk are statistically significant compared to their respective not exposed control cells $(P<.05)$.

the cytoplasmic proteolytic pathway have been highlighted. Results on cell proliferation are shown in Figure 2, where each data point is reported as percent of control unexposed cells within the same time exposure. Stimulating the cells with $0.1 \mu \mathrm{M}$ TPA, a tumor promoter able to activate protein kinase $\mathrm{C}$ in vivo and in vitro, caused a slighter increase in cell proliferation (from 8 to $10 \%$ at 24 hours and from 11 to $13 \%$ at 48 hours) and essentially no change in cell viability, as measured by the MTT reduction assay. Viability in exposed cells was not less than $85 \%$ of the respective controls (data not shown).

In order to test whether ELF-EMFs exposure causes an increase in cellular oxidative stress, thus favouring changes in protein structures, immunoblot analyses of protein carbonyl groups were performed. As shown in Figure 3, the exposure to ELF-EMFs led to a time dependent increase in protein oxidation. Particularly evident was the increase in carbonyl groups after ELF-EMFs exposure and in the presence of TPA, especially at 72 hours treatment $(1.67$-fold increase, $P<.05)$; see Figure 3.

Numerous publications reported on the ability of EGCG to act as a free radical scavenger $[34,36-39,52]$. The protective action of EGCG against the ELF-EMFs induced oxidative stress was assayed adding this polyphenol directly to the culture medium during exposure. The treatment with
$150 \mu \mathrm{M}$ EGCG caused, essentially, no change in cell viability as measured by the MTT reduction assay (data not shown). As shown in Figure 4, the enhancement in protein carbonyl groups, evident in cells exposed to the fields, was lowered in EGCG treated cells, demonstrating that EGCG protected cells from protein oxidation induced by ELF-EMFs exposure.

As abovementioned, the $20 \mathrm{~S}$ proteasome is the proteolytic system involved in the removal of oxidatively modified proteins [25-28]. The enzyme functionality was measured monitoring the cleavage of short synthetic peptides in whole cell extracts; in details, the ChT-L, T-L, BrAAP, and PGPH activities were assayed. The results obtained from the activity assays demonstrated that the most susceptible components to the fields were the ChT-L, T-L, and PGPH. In particular, the T-L and PGPH components presented a very similar behaviour. In fact, in the absence of TPA, the exposure to electromagnetic fields led to the activation of both the components with a 1.16-fold increase after 24 hours treatment $(P<.05)$. The ChT-L activity presented the maximum activation at 72 hours $(1.17$-fold increase, $P<$ $.05)$; see Figure 5. An evident activation of the components was also manifested after the simultaneous exposure to TPA. In detail, at 72 hours a 1.18-fold, a 1.2-fold and a 1.17-fold increase was evident for the T-L, PGPH, and ChT-L activity, respectively. 


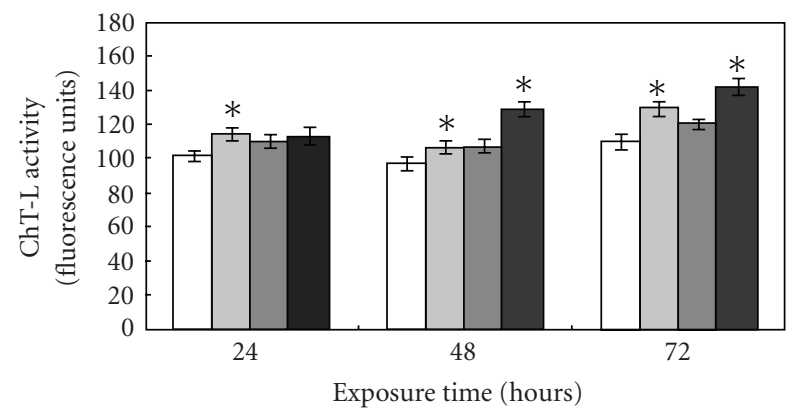

(a)

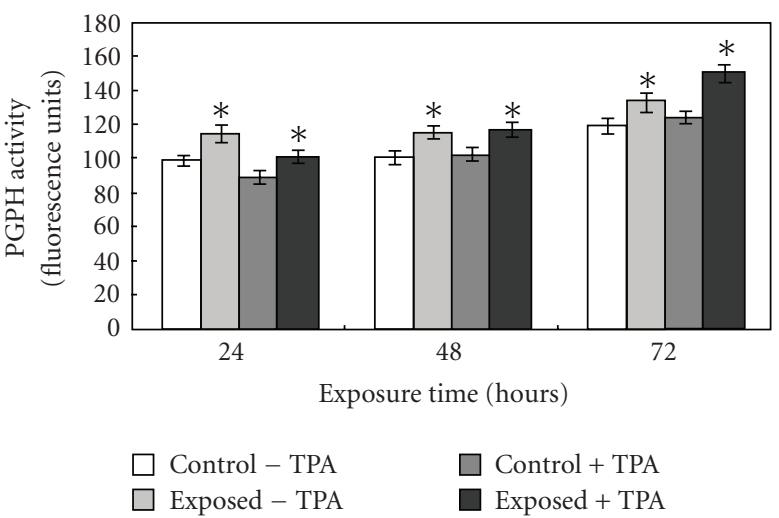

(c)

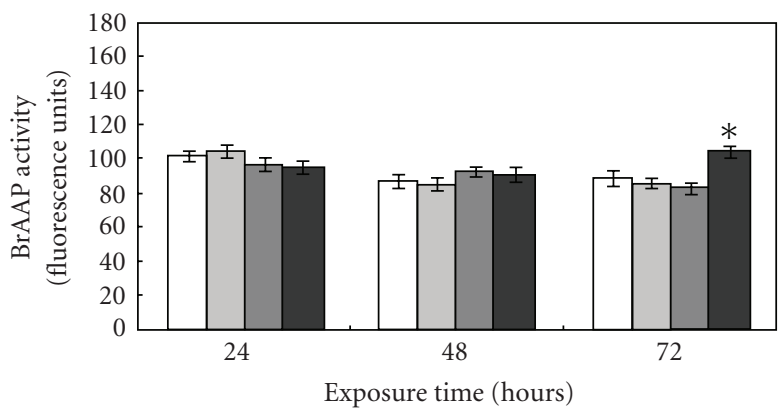

(b)

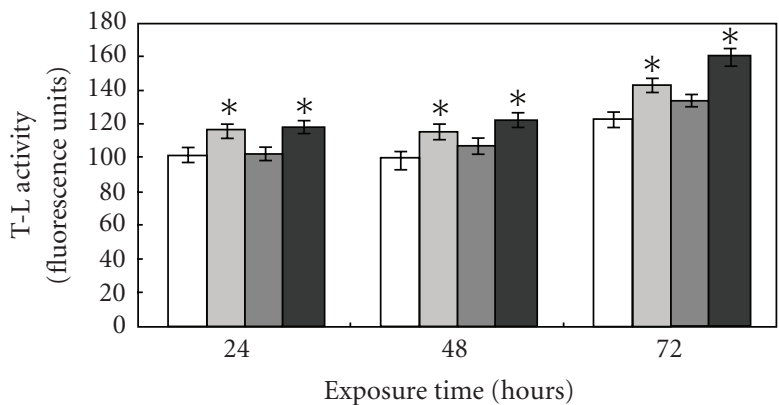

$\square$ Control - TPA
$\square$ Exposed - TPA

$\square$ Control + TPA

- Exposed + TPA

(d)

Figure 5: Proteasomal activities measured in cell lysates upon exposure to ELF-EMFs. Caco cells were treated or not with $0.1 \mu \mathrm{M}$ TPA for 24 , 48, and 72 hours; they were exposed to ELF-EMFs while the control dishes were placed under the same conditions in a solenoid with no field. After harvesting and lysing the cells, ChT-L (suc-Leu-Leu-Val-Tyr-AMC), T-L (Z-Leu-Ser-Thr-Arg-AMC) PGPH (Z-Leu-Leu-Glu-AMC), and BrAAP (Z-Gly-Pro-Ala-Leu-Ala-pAB) activities were executed in the cell extracts. Data are expressed as fluorescence arbitrary units subtracted of the values of control assays in the presence of specific inhibitors. Data are mean \pm SE of six separate experiments. Asterisks represent statistically significant differences from the respective control, not exposed, cultures: $P<.05$.

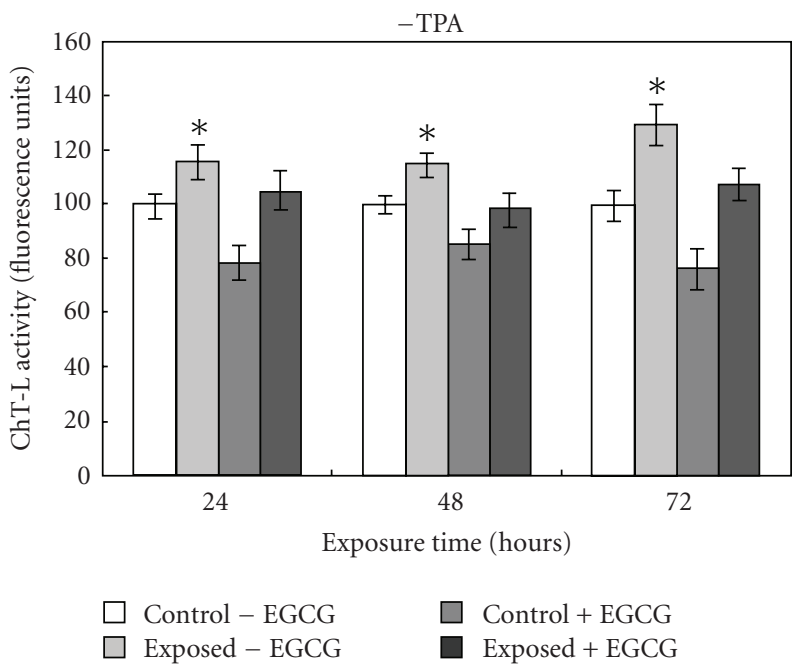

(a)

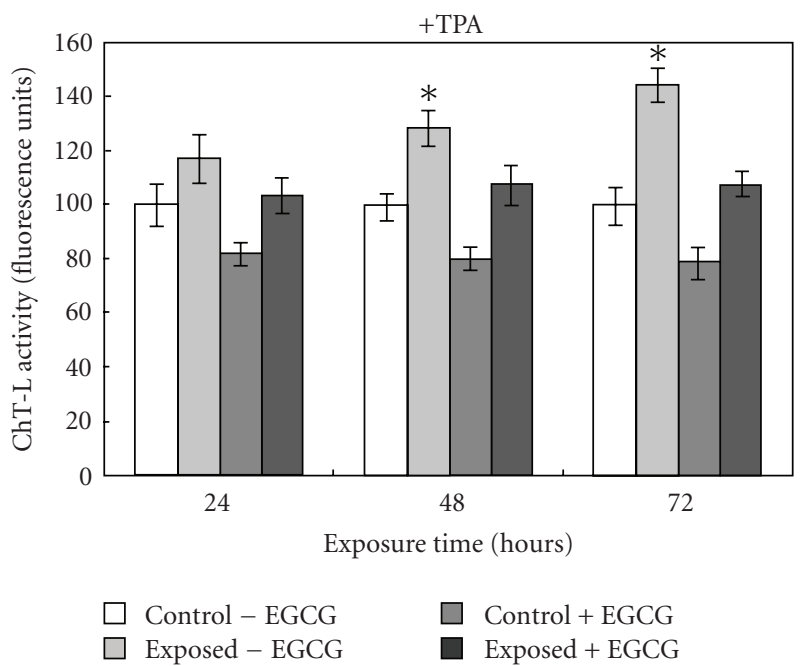

(b)

FIGURE 6: ChT-L activity measured in cell lysates upon exposure to ELF-EMFs and treatment with EGCG. Caco cells were treated or not with $150 \mu \mathrm{M}$ EGCG for 24, 48, and 72 hours; they were exposed to ELF-EMFs while the control dishes were placed under the same conditions in a solenoid with no field. After harvesting and lysing the cells the ChT-L (suc-Leu-Leu-Val-Tyr-AMC) activity was executed in the cell extracts. Data are expressed as fluorescence arbitrary units subtracted of the values of control assays in the presence of specific inhibitors. Data are mean \pm SE of six separate experiments. Asterisks represent statistically significant differences from the respective control, not exposed, cultures: $P<.05$. 


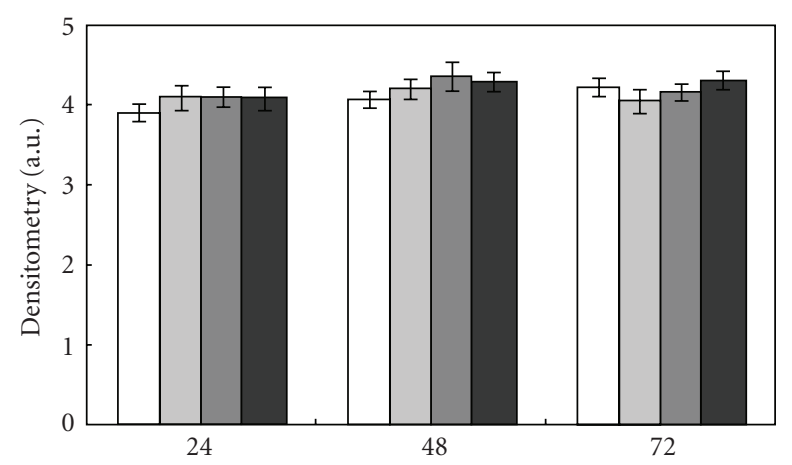

Exposure time (hours)

(a)

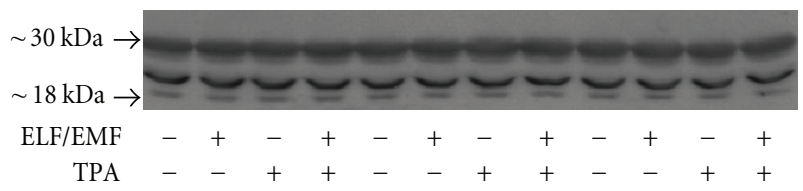

(b)

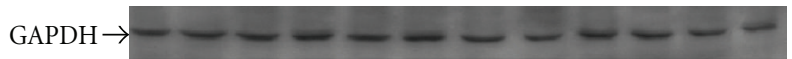

(c)

FIgure 7: Effect of ELF-EMFs exposure and TPA treatment on $20 \mathrm{~S}$ proteasome levels. Representative autoradiography of $20 \mathrm{~S}$ proteasome in Caco cells exposed to ELF-EMFs. The densitometric analysis from six separate blots provided for quantitative analysis of the amount of $20 \mathrm{~S}$ "core" is presented (a) and a representative Western blot is shown in (b). Equal protein loading was verified by using an anti-GAPDH antibody (c). The immunostaining was performed using an anti-20S proteasome antibody, and the detection was executed by the Enhanced Chemiluminescence Western blot analysis system.

Interestingly, the BrAAP component presented a peculiar behaviour since it was not affected at 24 hours and 48 hours, while a 1.25-fold increase was evident at 72 hours exposure $(P<.05)$; see Figure 5, (b).

In a recent study we have shown that EGCG has, besides its scavenging and antioxidant properties, a direct inhibitory effect on the $20 \mathrm{~S}$ proteasome [34]. When cells were exposed to the fields in the presence of EGCG the abovedescribed proteasome activation was blocked as shown in Figure 6 for the ChT-L activity. It is reasonable that the EGCG-dependent decrease in oxidized species results in a minor exposure of protein hydrophobic residues generating an environment not favorable for the proteasome to be activated.

In order to evaluate whether the differences observed in proteasome functionality were due to changes in $20 \mathrm{~S}$ proteasome expression levels, we performed immunoblottings using an anti-20S proteasome antibody. As shown in Figure 7, no differences were detected in the proteasome content in lysates obtained from treated and control cells, suggesting that the fields do not affect proteasome expression.

The protein p27 is a cell cycle regulator with a proapoptotic effect and is also known as a $20 \mathrm{~S}$ proteasome

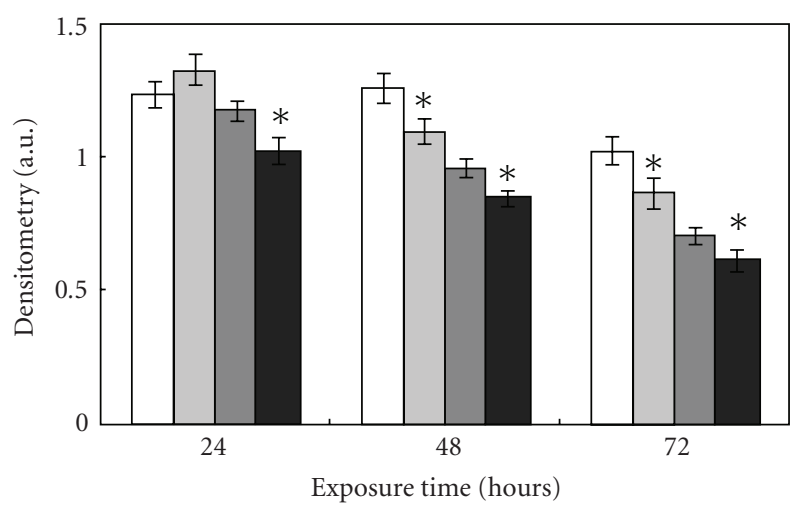

(a)

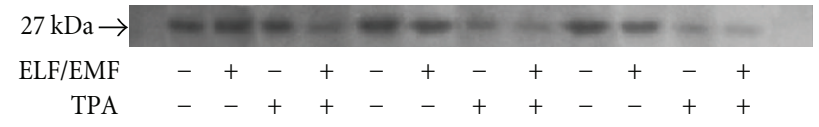

(b)

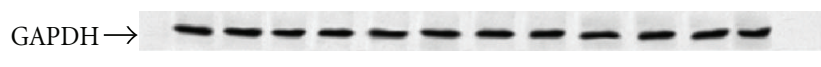

(c)

FIGURE 8: Effect of ELF-EMFs exposure and TPA treatment on p27 levels. Autoradiographs of p27 expression in Caco cells exposed to ELM-EMFs. The densitometric analysis from six separate blots provided for quantitative analysis is presented (a) and a representative Western blot is shown (b). Equal protein loading was verified by using an antibody directed against GAPDH (c). Caco cells were cultured with or without $0.1 \mu \mathrm{M}$ TPA for 24,48 , and 72 hours. After harvesting and lysing the cells, samples were subjected to SDSPAGE and electroblotted on a polyvinylidene fluoride membrane. The immunostaining was performed using anti-p27 antibodies, and the detection was executed by the Enhanced Chemiluminescence western blotting analysis system. Data points marked with an asterisk are statistically significant compared to their respective not exposed control cells $(P<.05)$.

substrate. Its levels are therefore considered a hallmark of proteasome functionality. The immunoblot analysis performed with an antibody specific for this protein, showed a time dependent decrease of p27 expression following ELFEMFs exposure. In the absence of TPA, a gradual decrease of p27 levels was detected reaching a 15\% decrease after 48 hours and 72 hours exposure. The presence of TPA led to an overall decrease of protein levels, detectable both in control and ELF-EMFs exposed cells. Moreover, p27 levels in ELFEMFs treated cells were a $10 \%$ lower than in unexposed control cells (Figure 8).

Previous findings suggest that conditions of mild oxidative stress, causing a rearrangement of cellular proteins structures with the consequent exposure of normally hidden hydrophobic residues, may induce an activation of the proteasome functionality [53, 54]. Considering this, the enhancement observed in the $20 \mathrm{~S}$ proteasome activity, being not associated to an upregulation of its synthesis, as demonstrated by the $20 \mathrm{~S}$ immunoblots, could be a consequence of the increase in the intracellular oxidative stress. It is possible that in order to counteract the toxicity associated 
to protein oxidation, cells promote the proteasome-mediated proteolytic pathway.

Furthermore, this increased activity could be related to the upregulation of the intracellular $\mathrm{Ca}^{2+}$ levels. An increase in $\left[\mathrm{Ca}^{2+}\right]$ in cells upon ELF-EMFs exposure was reported by numerous groups $[55,56]$, and it is known that this divalent cation is able to modulate proteasome activity, as suggested by Reshetnyak et al. regarding the ChT-L component. The proteasome activation could be associated with a change in the 20S structure with the adoption of an ordered 7fold symmetric pore conformation stabilized by interactions among a cluster of highly conserved residues (Tyr8, Asp9, Pro17 and Tyr26) [57]. This change lets the proteasome achieve an open conformation thus allowing the substrate to easily enter the proteolytic cavity. The ELF-EMF mediated Vmax increase could be a $\mathrm{Ca}^{2+}$ dependent event. In fact, SDS and $\mathrm{Ca}^{2+}$ behave in a similar way toward proteasome activation [58] and it has been shown that SDS is able to increase proteasome Vmax [59].

Upon ELF-EMFs exposure there was a decrease in p27 expression levels most likely because of the activation of the $20 \mathrm{~S}$ proteasome. Apoptosis is a normally occurring process which is used as a protective mechanism to remove damaged cells; therefore the observed downregulation of p27 expression, induced by both ELF-EMFs and TPA, may prevent the cells from utilizing that strategy in order to get rid of altered cells $[60,61]$.

ELF-EMFs effects are potentiated by stimulation with TPA, confirming the generally accepted notion that ELFEMFs behave as a tumor promoter but not as a tumour initiator $[1,62]$. In fact, it has been published that low TPA concentrations render the cells susceptible to other stimuli, and consequently the simultaneous exposure to ELF-EMFs lets the two factors act in a synergistic manner [63].

It is interesting to note that intracellular calcium concentration fluctuates upon ELF-EMFs exposure, affecting protein kinases activities and activating nuclear promoters. Recently, it has been demonstrated that $\left[\mathrm{Ca}^{2+}\right]$ is able to trigger ubiquitination of endoplasmic reticulum key receptors, such as inositol 1,4,5-tris-phosphate receptor [64]. This receptor binds to the antiapoptotic protein $\mathrm{Bcl}-\mathrm{X}(\mathrm{L})$, resulting in reduced endoplasmic reticulum $\mathrm{Ca}^{2+}$ concentration, increased oscillations of cytoplasmic $\left[\mathrm{Ca}^{2+}\right]$, and resistance to apoptosis [65]. This pathway might potentiate the antiapoptotic effect, investigated in this study, derived from an increase of p27 degradation.

\section{Conclusions}

The goal of the present study was to elucidate the effects of ELF-EMFs on the functionality of the $20 \mathrm{~S}$ proteasome, one of the major systems responsible for protein degradation, mainly involved in the removal of oxidized proteins. Our data show that the electromagnetic fields are able to affect the proteasome functionality inducing an increase in its proteolytic activity. The finding that EGCG, a natural compound with antioxidant properties, counteracts the ELF/EMFs related pro-oxidant effects demonstrate that this increase in proteasome activity is due to an increase in intracellular free radicals.

The modulation of the proteasome functionality may in turn affect indirectly various cellular pathways, that is, apoptosis in the human colon carcinoma cell line (Caco 2).

Further studies will be necessary to elucidate different susceptibilities to ELF-EMFs effects between normal and transformed cells in order to gain insight into the role of ELFEMFs in the carcinogenetic process.

Starting from the potential effect on cell proliferation and differentiation, changes in proteasome functionality, which could be the cause of an altered cell cycle, and the degree of protein oxidation will also be considered among the detrimental effects of electromagnetic fields.

\section{Abbreviations}

$\begin{array}{ll}\text { ELF-EMFs: } & \text { Extremely low frequency electromagnetic } \\ & \text { fields } \\ \text { PGPH: } & \text { Peptidyl-glutamyl peptide hydrolyzing } \\ \text { T-L: } & \text { Trypsin-like } \\ \text { ChT-L: } & \text { Chymotrypsin-like } \\ \text { BrAAP: } & \text { Branched chain amino acid preferring } \\ \text { SNAAP: } & \text { Small neutral amino acid preferring } \\ \text { EGCG: } & \text { Epigallocatechin-3-gallate } \\ \text { Suc: } & \text { Succinyl } \\ \text { AMC: } & \text { 7-amino-4-methyl-coumarin } \\ \text { Z: } & \text { Benzyloxycarbonyl } \\ \text { pAB: } & \text { 4-aminobenzoate } \\ \text { TPA: } & \text { 12-O-tetradecanoylphorbol-13-acetate } \\ \text { PABA: } & \text { 4-aminobenzoic acid }\end{array}$

\section{Acknowledgment}

This work was supported by a Grant of (Istituto Superiore Prevenzione e Sicurezza Lavoro, Italy ISPESL).

\section{References}

[1] A. Lacy-Hulbert, J. C. Metcalfe, and R. Hesketh, "Biological responses to electromagnetic fields," The FASEB Journal, vol. 12, no. 6, pp. 395-420, 1998.

[2] R. Saunders, "Static magnetic fields: animal studies," Progress in Biophysics and Molecular Biology, vol. 87, no. 2-3, pp. 225239, 2005.

[3] F. Regoli, S. Gorbi, N. MacHella, et al., "Pro-oxidant effects of extremely low frequency electromagnetic fields in the land snail Helix aspersa," Free Radical Biology and Medicine, vol. 39, no. 12, pp. 1620-1628, 2005.

[4] J. Rollwitz, M. Lupke, and M. Simkó, "Fifty-hertz magnetic fields induce free radical formation in mouse bone marrowderived promonocytes and macrophages," Biochimica et Biophysica Acta, vol. 1674, no. 3, pp. 231-238, 2004.

[5] F. I. Wolf, A. Torsello, B. Tedesco, et al., " $50-\mathrm{Hz}$ extremely low frequency electromagnetic fields enhance cell proliferation and DNA damage: possible involvement of a redox mechanism," Biochimica et Biophysica Acta, vol. 1743, no. 1-2, pp. 120-129, 2005.

[6] F. L. Cozens and J. C. Scaiano, "A comparative study of magnetic field effects on the dynamics of geminate and 
random radical pair processes in micelles," Journal of the American Chemical Society, vol. 115, no. 12, pp. 5204-5211, 1993.

[7] S. Roy, Y. Noda, V. Eckert, et al., "The phorbol 12-myristate 13 -acetate (PMA)-induced oxidative burst in rat peritoneal neutrophils is increased by a $0.1 \mathrm{mT}(60 \mathrm{~Hz})$ magnetic field," FEBS Letters, vol. 376, no. 3, pp. 164-166, 1995.

[8] W. Löschera and R. P. Liburdy, "Animal and cellular studies on carcinogenic effects of low frequency $(50 / 60-\mathrm{Hz})$ magnetic fields," Mutation Research, vol. 410, no. 2, pp. 185-220, 1998.

[9] A. Lisi, A. Foletti, M. Ledda, et al., "Extremely low frequency $7 \mathrm{~Hz} 100$ microT electromagnetic radiation promotes differentiation in the human epithelial cell line HaCaT," Electromagnetic Biology and Medicine, vol. 25, no. 4, pp. 269280, 2006

[10] M. Feychting, A. Ahlbom, and L. Kheifets, "EMF and health," Annual Review of Public Health, vol. 26, pp. 165-189, 2005.

[11] I. M. o. t. E. o. C. International Agency for Research on Cancer, "Non-ionizing radiation-part 1: static and extremely lowfrequency (ELF) electric and magnetic fields," 2002.

[12] H. Wu, K. Ren, W. Zhao, G. E. Baojian, and S. Peng, "Effect of electromagnetic fields on proliferation and differentiation of cultured mouse bone marrow mesenchymal stem cells," Journal of Huazhong University of Science and Technology, vol. 25, no. 2, pp. 185-187, 2005.

[13] K. Zwirska-Korczala, J. Jochem, M. Adamczyk-Sowa, et al., "Effect of extremely low frequency electromagnetic fields on cell proliferation, antioxidative enzyme activities and lipid peroxidation in 3T3-L1 preadipocytes - an in vitro study," Journal of Physiology and Pharmacology, vol. 56, supplement 6, pp. 101-108, 2005.

[14] I. Nordenson, K. H. Mild, G. Andersson, and M. Sandström, "Chromosomal aberrations in human amniotic cells after intermittent exposure to fifty hertz magnetic fields," Bioelectromagnetics, vol. 15, no. 4, pp. 293-301, 1994.

[15] M. Simkó, R. Kriehuber, D. G. Weiss, and R. A. Luben, "Effects of $50 \mathrm{~Hz}$ EMF exposure on micronucleus formation and apoptosis in transformed and nontransformed human cell lines," Bioelectromagnetics, vol. 19, no. 2, pp. 85-91, 1998.

[16] H. Lai and N. P. Singh, "Acute exposure to a $60 \mathrm{~Hz}$ magnetic field increases DNA strand breaks in rat brain cells," Bioelectromagnetics, vol. 18, no. 2, pp. 156-165, 1997.

[17] O. Holian, R. D. Astumian, R. C. Lee, H. M. Reyes, B. M. Attar, and R. J. Walter, "Protein kinase C activity is altered in HL60 cells exposed to $60 \mathrm{~Hz}$ AC electric fields," Bioelectromagnetics, vol. 17, no. 6, pp. 504-509, 1996.

[18] S. C. Miller and M. J. Furniss, "Bruton's tyrosine kinase activity and inositol 1,4,5-trisphosphate production are not altered in DT40 lymphoma B cells exposed to power line frequency magnetic fields," The Journal of Biological Chemistry, vol. 273, no. 49 , pp. $32618-32626,1998$.

[19] A. Morelli, S. Ravera, I. Panfoli, and I. M. Pepe, "Effects of extremely low frequency electromagnetic fields on membraneassociated enzymes," Archives of Biochemistry and Biophysics, vol. 441, no. 2, pp. 191-198, 2005.

[20] F. Salamino, R. Minafra, V. Grano, et al., "Effect of extremely low frequency magnetic fields on calpain activation," Bioelectromagnetics, vol. 27, no. 1, pp. 43-50, 2006.

[21] J. Basbous, I. Jariel-Encontre, T. Gomard, G. Bossis, and M. Piechaczyk, "Ubiquitin-independent-versus ubiquitindependent proteasomal degradation of the c-Fos and Fra-1 transcription factors: is there a unique answer?" Biochimie, vol. 90, no. 2, pp. 296-305, 2008.
[22] B. Li and Q. P. Dou, "Bax degradation by the ubiquitin proteasome-dependent pathway: involvement in tumor survival and progression," Proceedings of the National Academy of Sciences of the United States of America, vol. 97, no. 8, pp. 3850-3855, 2000.

[23] Y. Yang, C.-C. H. Li, and A. M. Weissman, "Regulating the p53 system through ubiquitination," Oncogene, vol. 23, no. 11, pp. 2096-2106, 2004.

[24] H. C. Drexler, "The role of p27Kip1 in proteasome inhibitor induced apoptosis," Cell Cycle, vol. 2, no. 5, pp. 438-441, 2003.

[25] A. J. Rivett, "Preferential degradation of the oxidatively modified form of glutamine synthetase by intracellular mammalian proteases," The Journal of Biological Chemistry, vol. 260, no. 1, pp. 300-305, 1985.

[26] T. Grune, "Oxidative stress, aging and the proteasomal system," Biogerontology, vol. 1, no. 1, pp. 31-40, 2000.

[27] T. Grune, K. Merker, G. Sandig, and K. J. A. Davies, "Selective degradation of oxidatively modified protein substrates by the proteasome," Biochemical and Biophysical Research Communications, vol. 305, no. 3, pp. 709-718, 2003.

[28] T. Jung and T. Grune, "The proteasome and its role in the degradation of oxidized proteins," IUBMB Life, vol. 60, no. 11, pp. 743-752, 2008.

[29] J. Lowe, D. Stock, B. Jap, P. Zwickl, W. Baumeister, and R. Huber, "Crystal structure of the $20 \mathrm{~S}$ proteasome from the archaeon T. acidophilum at 3.4 A resolution," Science, vol. 268, no. 5210, pp. 533-539, 1995.

[30] C. Cardozo, "Catalytic components of the bovine pituitary multicatalytic proteinase complex (proteasome)," Enzyme and Protein, vol. 47, no. 4-6, pp. 296-305, 1993.

[31] M. Orlowski, "The multicatalytic proteinase complex, a major extralysosomal proteolytic system," Biochemistry, vol. 29, no. 45, pp. 10289-10297, 1990.

[32] M. Orlowski and S. Wilk, "Catalytic activities of the $20 \mathrm{~S}$ proteasome, a multicatalytic proteinase complex," Archives of Biochemistry and Biophysics, vol. 383, no. 1, pp. 1-16, 2000.

[33] M. Orlowski, M. Cardozo C., and C. Michaud, "Evidence for the presence of five distinct proteolytic components in the pituitary multicatalytic proteinase complex. Properties of two components cleaving bonds on the carboxyl side of branched chain and small neutral amino acids," Biochemistry, vol. 32, no. 6, pp. 1563-1572, 1993.

[34] A. Pettinari, M. Amici, M. Cuccioloni, M. Angeletti, E. Fioretti, and A. M. Eleuteri, "Effect of polyphenolic compounds on the proteolytic activities of constitutive and immuno-proteasomes," Antioxidants and Redox Signaling, vol. 8, no. 1-2, pp. 121-129, 2006.

[35] S. Nam, D. M. Smith, and Q. P. Dou, "Ester bond-containing tea polyphenols potently inhibit proteasome activity in vitro and in vivo," The Journal of Biological Chemistry, vol. 276, no. 16, pp. 13322-13330, 2001.

[36] S.-J. Lee and K.-W. Lee, "Protective effect of (-)epigallocatechin gallate against advanced glycation endproducts-induced injury in neuronal cells," Biological and Pharmaceutical Bulletin, vol. 30, no. 8, pp. 1369-1373, 2007.

[37] M. Glei and B. L. Pool-Zobel, "The main catechin of green tea, (-)-epigallocatechin-3-gallate (EGCG), reduces bleomycininduced DNA damage in human leucocytes," Toxicology in Vitro, vol. 20, no. 3, pp. 295-300, 2006.

[38] S. Costa, A. Utan, R. Cervellati, E. Speroni, and M. C. Guerra, "Catechins: natural free-radical scavengers against ochratoxin A-induced cell damage in a pig kidney cell line (LLC-PK1)," 
Food and Chemical Toxicology, vol. 45, no. 10, pp. 1910-1917, 2007.

[39] C. Thephinlap, S. Ounjaijean, U. Khansuwan, S. Fucharoen, J. B. Porter, and S. Srichairatanakool, "Epigallocatechin-3gallate and epicatechin-3-gallate from green tea decrease plasma non-transferrin bound iron and erythrocyte oxidative stress," Medicinal Chemistry, vol. 3, no. 3, pp. 289-296, 2007.

[40] M. M. Bradford, "A rapid and sensitive method for the quantitation of microgram quantities of protein utilizing the principle of protein dye binding," Analytical Biochemistry, vol. 72, no. 1-2, pp. 248-254, 1976.

[41] N. Santoro, A. Lisi, D. Pozzi, E. Pasquali, A. Serafino, and S. Grimaldi, "Effect of extremely low frequency (ELF) magnetic field exposure on morphological and biophysical properties of human lymphoid cell line (Raji)," Biochimica et Biophysica Acta, vol. 1357, no. 3, pp. 281-290, 1997.

[42] F. W. Holtsberg, M. R. Steiner, J. N. Keller, R. J. Mark, M. P. Mattson, and S. M. Steiner, "Lysophosphatidic acid induces necrosis and apoptosis in hippocampal neurons," Journal of Neurochemistry, vol. 70, no. 1, pp. 66-76, 1998.

[43] T. Mosmann, "Rapid colorimetric assay for cellular growth and survival: application to proliferation and cytotoxicity assays," The Journal of Immunological Methods, vol. 65, no. 1-2, pp. 55-63, 1983.

[44] A. M. Eleuteri, M. Angeletti, G. Lupidi, R. Tacconi, L. Bini, and E. Fioretti, "Isolation and characterization of bovine thymus multicatalytic proteinase complex," Protein Expression and Purification, vol. 18, no. 2, pp. 160-168, 2000.

[45] S. Wilk and M. Orlowski, "Evidence that pituitary cationsensitive neutral endopeptidase is a multicatalytic protease complex," Journal of Neurochemistry, vol. 40, no. 3, pp. 842$849,1983$.

[46] J. Almenoff and M. Orlowski, "Membrane-bound kidney neutral metalloendopeptidase: interaction with synthetic substrates, natural peptides, and inhibitors," Biochemistry, vol. 22, no. 3, pp. 590-599, 1983.

[47] G. Pfleiderer, "Isolation of an aminopeptidase from kidney particles," in Methods Enzymology, pp. 514-521, 1970.

[48] L. R. Dick, A. A. Cruikshank, L. Grenier, F. D. Melandri, S. L. Nunes, and R. L. Stein, "Mechanistic studies on the inactivation of the proteasome by lactacystin: a central role for closto-lactacystin $\beta$-lactone," The Journal of Biological Chemistry, vol. 271, no. 13, pp. 7273-7276, 1996.

[49] A. M. Eleuteri, R. A. Kohanski, C. Cardozo, and M. Orlowski, "Bovine spleen multicatalytic proteinase complex (proteasome). Replacement of X, Y, and Z subunits by LMP7, LMP2, and MECL1 and changes in properties and specificity," The Journal of Biological Chemistry, vol. 272, no. 18, pp. 1182411831, 1997.

[50] C. Marchini, M. Angeletti, A. M. Eleuteri, A. Fedeli, and E. Fioretti, "Aspirin modulates LPS-induced nitric oxide release in rat glial cells," Neuroscience Letters, vol. 381, no. 1-2, pp. 8691, 2005.

[51] R. R. Sokal and F. J. Rohlf, Biometry: The Principles and Practice of Statistics in Biological Research, W. H. Freeman, New York, NY, USA, 1994.

[52] H. Raza and A. John, "In vitro effects of tea polyphenols on redox metabolism, oxidative stress, and apoptosis in PC12 cells," Annals of the New York Academy of Sciences, vol. 1138, pp. 358-365, 2008.

[53] K. J. A. Davies, "Degradation of oxidized proteins by the $20 \mathrm{~S}$ proteasome," Biochimie, vol. 83, no. 3-4, pp. 301-310, 2001.

[54] K. J. A. Davies and R. Shringarpure, "Preferential degradation of oxidized proteins by the $20 \mathrm{~S}$ proteasome may be inhibited in aging and in inflammatory neuromuscular diseases," $\mathrm{Neu}$ rology, vol. 66, no. 2, supplement 1, pp. S93-S96, 2006.

[55] C. R. McCreary, S. J. Dixon, L. J. Fraher, J. J. L. Carson, and F. S. Prato, "Real-time measurement of cytosolic free calcium concentration in Jurkat cells during ELF magnetic field and evaluation of the role of cell cycle," Bioelectromagnetics, vol. 27, no. 5, pp. 354-364, 2006.

[56] E. Lindstrom, P. Lindstrom, A. Berglund, K. H. Mild, and E. Lundgren, "Intracellular calcium oscillations induced in a Tcell line by a weak $50 \mathrm{~Hz}$ magnetic field," Journal of Cellular Physiology, vol. 156, no. 2, pp. 395-398, 1993.

[57] A. Förster, F. G. Whitby, and C. P. Hill, "The pore of activated $20 \mathrm{~S}$ proteasomes has an ordered 7-fold symmetric conformation," The EMBO Journal, vol. 22, no. 17, pp. 43564364, 2003.

[58] Y. K. Reshetnyak, R. P. Kitson, M. Lu, and R. H. Goldfarb, "Conformational and enzymatic changes of 20S proteasome of rat natural killer cells induced by mono- and divalent cations," Journal of Structural Biology, vol. 145, no. 3, pp. 263-271, 2004.

[59] M. Matsuishi and A. Okitani, "Proteasome from rabbit skeletal muscle: some properties and effects on muscle proteins," Meat Science, vol. 45, no. 4, pp. 451-462, 1997.

[60] R. Palumbo, D. Capasso, F. Brescia, et al., "Effects on apoptosis and reactive oxygen species formation by Jurkat cells exposed to $50 \mathrm{~Hz}$ electromagnetic fields," Bioelectromagnetics, vol. 27, no. 2, pp. 159-162, 2006.

[61] M. T. Santini, A. Ferrante, G. Rainaldi, P. Indovina, and P. L. Indovina, "Extremely low frequency (ELF) magnetic fields and apoptosis: a review," International Journal of Radiation Biology, vol. 81, no. 1, pp. 1-11, 2005.

[62] B. Holmberg, "Magnetic fields and cancer: animal and cellular evidence-an overview," Environmental Health Perspectives, vol. 103, supplement 2, pp. 63-67, 1995.

[63] D. Richard, S. Lange, T. Viergutz, R. Kriehuber, D. G. Weiss, and S. Myrtill, "Influence of $50 \mathrm{~Hz}$ electromagnetic fields in combination with a tumour promoting phorbol ester on protein kinase $\mathrm{C}$ and cell cycle in human cells," Molecular and Cellular Biochemistry, vol. 232, no. 1-2, pp. 133-141, 2002.

[64] K. J. Alzayady and R. J. H. Wojcikiewicz, "The role of $\mathrm{Ca}^{2+}$ in triggering inositol 1,4,5-trisphosphate receptor ubiquitination," Biochemical Journal, vol. 392, no. 3, pp. 601-606, 2005.

[65] C. Li, X. Wang, H. Vais, C. B. Thompson, J. K. Foskett, and $\mathrm{C}$. White, "Apoptosis regulation by Bcl-xL modulation of mammalian inositol 1,4,5-trisphosphate receptor channel isoform gating," Proceedings of the National Academy of Sciences of the United States of America, vol. 104, no. 30, pp. 12565-12570, 2007. 


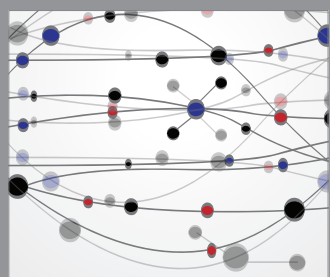

The Scientific World Journal
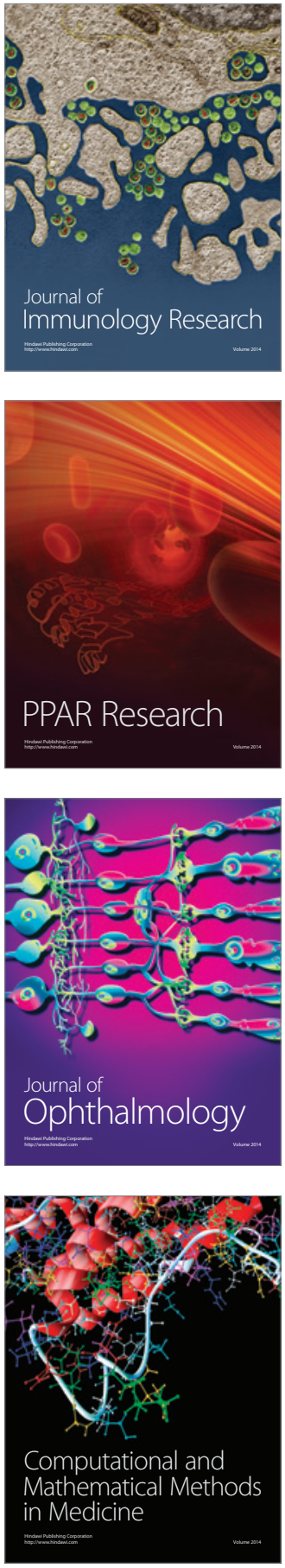

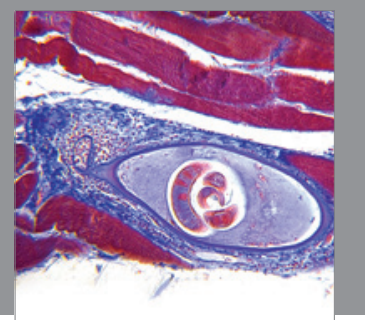

Gastroenterology

Research and Practice
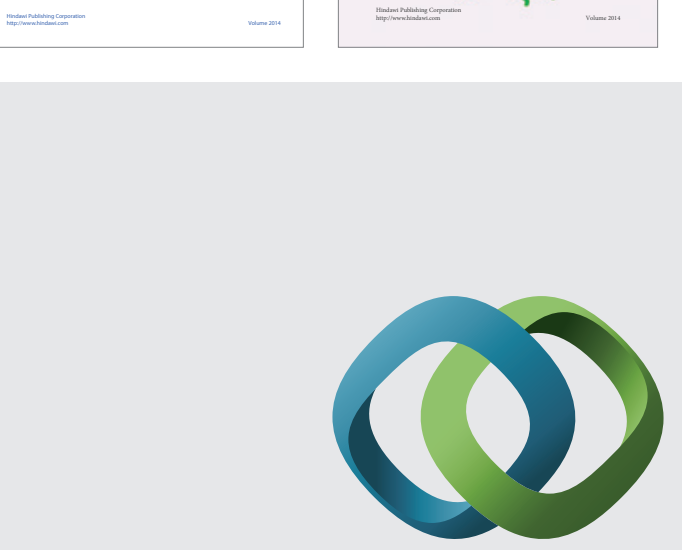

\section{Hindawi}

Submit your manuscripts at

http://www.hindawi.com
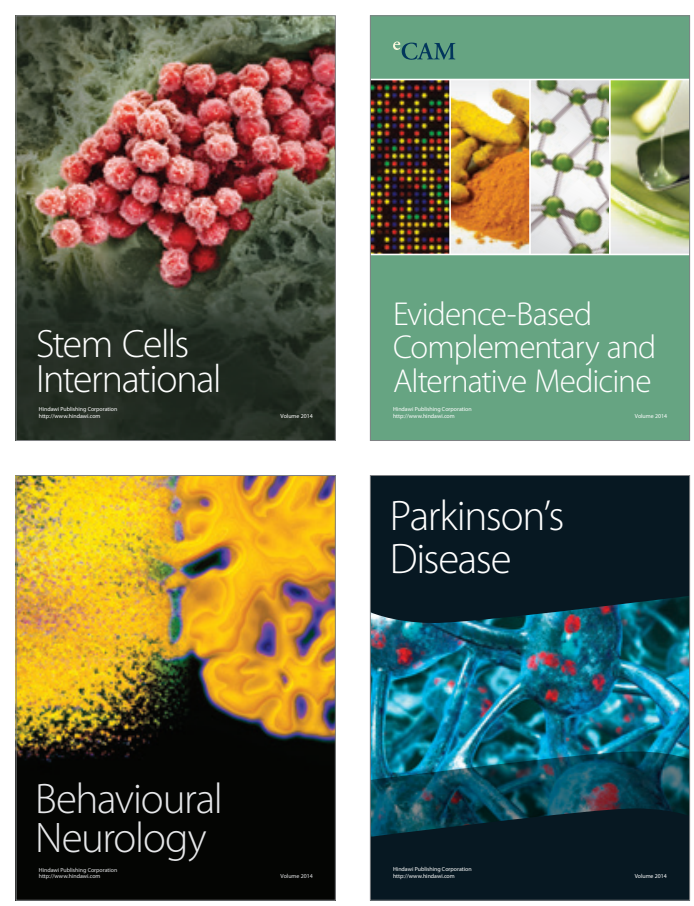

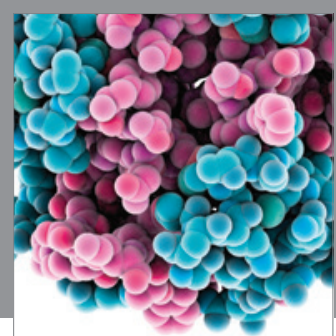

Journal of
Diabetes Research

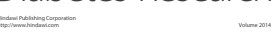

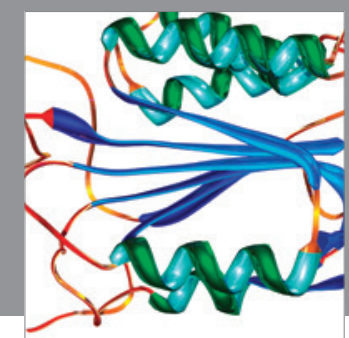

Disease Markers
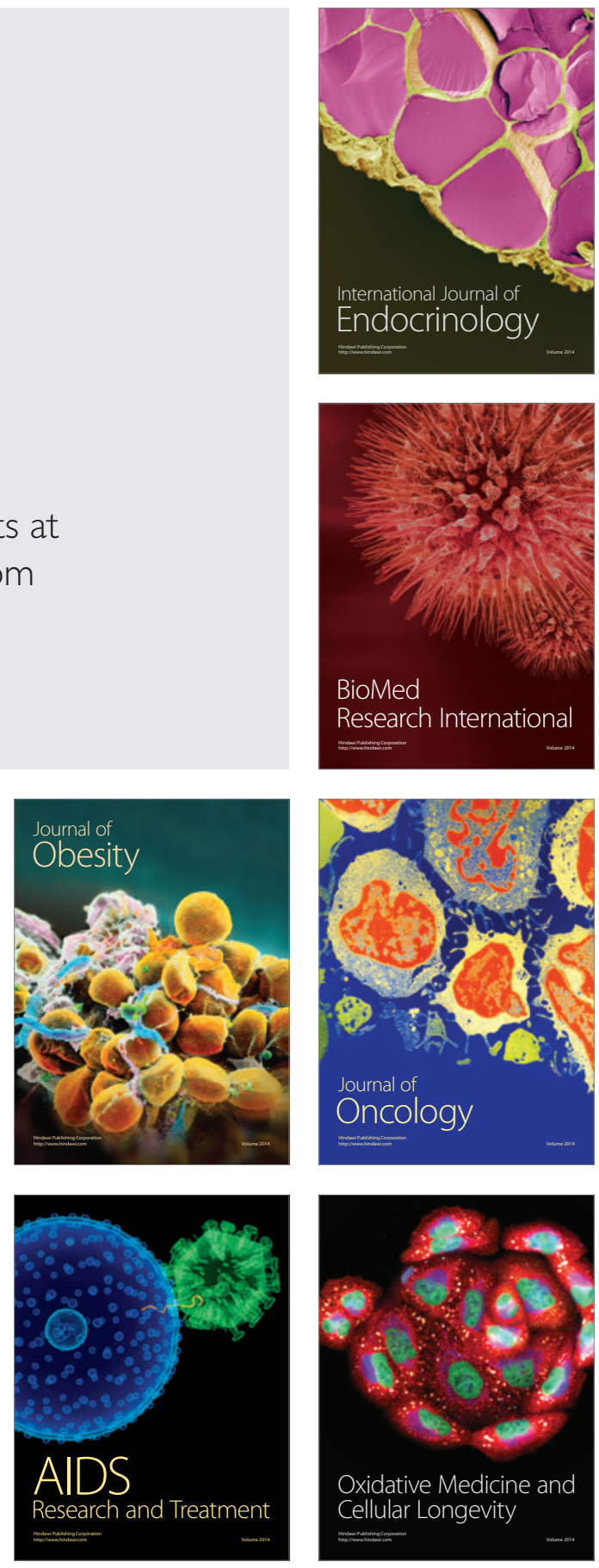